\title{
Investigating the ways parents perceive their preschool aged children's influence on their food purchase behaviour and brand preference
}

\author{
Tímea Tina Kásler \\ Corvinus University of Budapest
}

\section{THE AIMS OF THE PAPER}

To explore to what extent children exert influence on the food purchase behaviour of their parents. The study further analyses what role brand preferences of children have on the food consumption of their families according to their parents.

\section{METHODOLOGY}

To obtain a deeper understanding of what brand preferences are present in the lives of preschool children and how these affect the family consumption, in-depth interviews were conducted among the parents of preschool (3-6 year-old) children in Hungary. All of the seven regions of Hungary were included in the sample, the interviews were recorded, then transcribed. The sample of size $\mathrm{N}=15$ was then analysed via NVivo. The in-depth interviews were followed by an in-store observation of most participants.

\section{MOST IMPORTANT RESULTS}

Findings confirm that children develop preferences for brands even at such a young age. Most respondents recalled switching brands from the food and beverage industry due to their children's preferences.

Even though literature in the child consumer behaviour field is vast, research is scarce regarding this certain age group. The current study can be of great use to brand managers, to help build relationships with young consumers and their families. A robust child-brand relationship nurtured now, can help a firm develop competitive advantage in the long term. It can further be applicable in the design of product and communication strategies.

\section{RECOMMENDATIONS}

The current research may be supportive when considering the future of children's food marketing and even tackling the issue of childhood obesity. The results reflected that, the majority of preferred brands by children were sweets and savoury snacks, the paper suggest numerous possible implications for public health policy makers. The paper further highlights the shifts in brand usage within families, in other words those products that families are likely to substitute once their child starts building their own relationship and brand preferences.

Keywords: preschool-aged children, brand preference, consumer behaviour, qualitative study

DOI: 10.15170/MM.2020.54.02.06 


\section{INTRODUCTION}

From birth onwards, children consume an extensive amount of products, simultaneously influencing the purchasing behaviour of their parents. Children's brand preferences are taken into account in approximately one fifth of all purchase decisions (Page et al. 2018). Children mainly influence the households they live in regarding lower value and own consumption goods (McNeal 1992), according to the Federal Trade Commission (2012), companies in the US spend $\$ 870$ million marketing foods to children under 12 years. Carbonated beverages, fast food, and breakfast cereals account for $63 \%$ of the total food, and beverages marketing expenditure (Leibowitz et al. 2012).

Simultaneously, the purchase behaviour of families has shifted over time. Not only has there been a transformation of family compositions: women started to work outside the home and families became smaller (Fiates et al. 2008). According to the statistics of $\mathrm{KSH}$, half of the marriages in Hungary end with a divorce, while the number of patchwork families are growing (Spéder 2003), which increased the importance attributed to each child (Fiates et al. 2008). According to Pólya and Horváth (2011), the role of children within the family is rising due to the increase of one-parent families, less children per families and the growth of high-income families. Families also spend more time shopping together (Owens \& Hofferth 2001). Studies also found that reverse socialization exists, where consumer socialization occurs from children to parents (Ekström 2007). Adults are also prone to change their consumption habits through the experience of major life events (for example the birth of a child) (Koschate - Fischer et al. 2018). This was also confirmed by a Hungarian study conducted by Malota et al. (2018), who found that different household types have different food purchasing preferences.

In her paper, Pólya (2012) discusses the children's roles regarding the family internal decisionmaking. The paper's conclusion outlines that although children have great influential power, there are still great gaps regarding their exact roles in this process in the literature. Therefore, it is important to further study the purchase behaviour of children in the family setting. Furthermore, brand preferences of young adults have been measured, however, the differences in small children have been neglected. Yet, these preferences can influence the entire family's consumption pattern.

\section{LITERATURE REVIEW}

The current paper examines preschool-aged children, typically between the age of 3 to 6 . Like adults, the preschool-age group engage with a vast amount of brands. The way children impact their parents' consumption has been studied in the past, however the studies are mainly limited to in-store observations (Thomas \& Garland 1993, Page et al. 2018), while none of the papers focused solely on the preschool age group. O'Dougherty et al. (2006) studied the decision-making processes of adults around food purchases when young children are present. In half of the observations, a child initiated a request, half of these requests were for sweets or snacks. Brands and marketing appeared to be a factor in $28.6 \%$ of the selections. Thomas and Garland (1993) found, that shoppers on weekly grocery shopping spent $24 \%$ more, and took $10 \%$ longer when accompanied by children. Page et al. (2018) observed shoppers across four grocery retail outlets and found contradicting evidence to Thomas and Garland (1993). Accompanied shoppers took less time to buy and spend the same amount of money. The paper suggests that more persuasion attempts take place at home. Children may not influence the quantity, price, or categories of items purchased, but may influence the specific brand chosen (Page et al. 2018). Berey and Pollay (1968) suggest that the child influences consumer decisions based on their assertiveness and the mother's level of child centeredness. However, it has to be noted, that this study was also conducted on schoolchildren, regarding cereals only. Furthermore, Hsieh et al. (2006) study on parental influence on children indicated that mothers with concept-oriented (incorporating child's opinions) and fathers with socio-oriented communication (encourage proper normative behaviour) are more likely to influence their children's brand attitudes. In their study, Koschate-Fischer et al. (2018) found that first-time life events (such as the birth of a child) lead to increased innovativeness regarding purchase decisions, thus new parents are willing to try new brands of various products (Koschate-Fischer et al. 2018). Interestingly, children's attempts to influence purchases may decrease somewhat with age depending on the type of product, but a mother's yielding to request increases with age (Ward \& Wackman 1972).

Scientific papers discussing the participation of preschool children in the shopping process are rather limited. Drenten et al. (2008) had a very alternative approach to this question by using dramatic play to recreate a grocery store shopping context 
and were the first to do so. Findings indicated that even very young children are able to successfully adopt and utilize adult shopping scripts within the grocery store shopping context. Another study by Carruth et al. (2000) looked into preschoolers' food product choices at a simulated point of purchase. The study concluded that preschool children's food selections were influenced by a single attribute of the product packaging between ages 5 to 6 .

In the past, numerous papers dealt with the brand preferences of schoolchildren (Halford et al. 2007, Boyland \& Halford 2013). However, once again, preschool children remain understudied, even though by the age of 2 , children already make consumer decisions (John 1999), they are frequent viewers of television channels and are acquainted with advertised brands (Hite \& Hite 1995). This was underlined by the study of Kasler (2017), where the influence of television consumption on preschool children's brand awareness was explored. The results suggested that an increased television consumption affects children's consumer behaviour, as the knowledge of brands was higher amongst those children, who viewed television daily. Kim et al. (2016) found that traditional media advertising expenditures positively relate with brand affinity for children and mothers, while product placement relates positively with children's brand affinity but not with mothers' brand affinity. Children seemed to have a greater influence on mothers' brand preferences and mothers seemed to have less influence on children's brand preferences. In their paper, Hite and Hite (1995) looked into when consumers first begin to systematically choose familiar brands. The paper examined reliance on visual brand attributes such as brand name and packaging, in comparison to functional product attributes such as taste of children ages 2 to 6 . Children relied more on brand cues than taste in basing their judgements. Findings indicated that even very young children relied on non-functional perceptual brand attributes when making brand choices (Hite \& Hite 1995).

Conversely, despite the contributions made, several questions remain. The literature review shows that despite the growing importance of children as consumers, few studies have tried to understand the ways children influence the food purchase behaviour of their families and what role their brand preferences have on this process. To fill these gaps, this paper proposes in-depth interviews with the parents of preschool aged children, followed by an observation allowing to further understand brand preferences of children and how these influence parental purchase behaviour.

\section{METHODOLOGY}

In order to understand the ways children affect their families food purchase behaviours, in-depth interviews were conducted with 15 parents $(\mathrm{N}=15)$ of preschool aged (3-6 year old) children in various regions of Hungary. The main reason for choosing this methodology was, that when children are too young to provide reliable self-reports, it is necessary to use parent reports (Borgers et al. 2001). The sample size was determined by looking at past studies using the in-depth interview technique, such as the study of Maubach et al. (2009), where the influence of parents' food purchasing behaviours in supermarkets and away-from-home settings was explored. The paper also conducted individual in-depth interviews with 15 parents in New Zealand (Maubach et al. 2009). The entire population of the current study consisted of mothers and fathers who have children between the ages of 3-6 and live in Hungary. Prior to the interview, the participants were informed about the purpose of the research. The participants signed a letter of consent that all materials can be used and published for research purposes. Each interview's time span varied between an hour and an hour and a half. The interview took place either in the home of the participants or in a neutral environment like a quiet café. The interviews were all held in Hungarian.

The in-depth interviews were semi-structured, where the respondents answered pre-set openended questions. The questions and topics were pre-prepared before the interview in the form of an interview guide, yet leaving the possibility during the interview to skip a question if the participant had already answered it, probing by asking about certain questions in more detail and clarifying terms where required. The questions were formulated as simple as possible and structured into seven separate topics. Each topic was introduced in a few sentences. The topics ranged from the personal data of the families, to purchasing behaviour, to brand preferences and eating routines.

In terms of sampling strategies, maximum-variety sampling was applied in order to capture the heterogeneity in the population. This is a special kind of purposive sample that is suitable for a smaller sample size. In order to cover the entire Hungarian region, in the first stage, participants were selected so that at least one participant lived in one of the seven Hungarian regions. Once all the regions were covered, participants were selected further to make sure various income levels and education levels were covered in the sample. Interviews were 
audio-recorded with the respondent's permission. All the transcripts were entered into an NVivo database to facilitate coding and data management. The reason NVivo was used instead of simple content analysis was to organize the data and to accelerate the coding and analysing process. The transcripts were coded using methods of constant comparison, an iterative process where data were reviewed and re-reviewed as new themes emerged.

The sample was rather unbalanced in terms of gender with only two male participants. The average age was 33, whereas the oldest participant was 43 years old and the youngest a 24 year old mother of two. Two respondents only had one child, while the largest family was a mother with six children. When looking at the age and the gender of only the preschool aged children in the sample, 13 children in the sample were girls and 7 boys. The age of the children in the sample ranged between 3 and 6 , the mean age being 4,2 . One mother had identical twins. 12 of the respondents were married, one respondent was divorced, while two respondents were not married to their partners. The income level of the participants was determined by the question aiming to control social desirability bias: 'What percentage of your monthly income do you spend on groceries'. Three respondents claimed they spend more than $50 \%$ of their monthly income, they were grouped in the low-income category. At the same time, four respondents claimed to spend less than $25 \%$ of their monthly income, they were grouped in the high-income household category. The average answer to this question was $30 \%$. Attributes for all participants are presented in the table below (see Table 1). Table 1 only contains detailed information of children who are in the preschool age. The results were first evaluated independently after transcribing each interview, then the key elements were determined that were able to provide a deeper understanding of the previously identified topics, in accordance with the interpretative methodology.

Table 1. Attributes of participants using NVivo

\begin{tabular}{|c|c|c|c|c|c|c|c|c|c|c|}
\hline Participants & Age & $\begin{array}{l}\text { Age of } \\
\text { child }\end{array}$ & $\begin{array}{l}\text { Gender } \\
\text { of child }\end{array}$ & Income & Region & Allergy & Education & Gender & $\begin{array}{c}\text { Media } \\
\text { consump- } \\
\text { tion }\end{array}$ & $\begin{array}{c}\text { Number of } \\
\text { children }\end{array}$ \\
\hline 1. & $30-34$ & 3 & $\mathrm{~F}$ & Average & Rural & No & $\begin{array}{c}\text { Secondary } \\
\text { school }\end{array}$ & Female & High & 1 \\
\hline 2. & $40+$ & 5 & $\mathrm{~F}$ & High & Rural & No & University & Male & Low & 3 \\
\hline 3. & $35-40$ & 4 & M & Average & Rural & No & University & Female & Low & 4 \\
\hline 4. & $35-40$ & 6 & $\mathrm{~F}$ & Low & Rural & No & $\begin{array}{c}\text { Primary } \\
\text { school }\end{array}$ & Female & High & 6 \\
\hline 5. & $30-34$ & 4 & M & High & Urban & No & University & Female & High & 2 \\
\hline 6. & $30-34$ & 4,5 & $\mathrm{~F}, \mathrm{~F}$ & Average & Rural & Yes both & $\begin{array}{c}\text { Secondary } \\
\text { school }\end{array}$ & Female & Average & 3 \\
\hline 7. & $30-34$ & 3,4 & $\mathrm{M}, \mathrm{F}$ & Average & Rural & No & University & Female & Average & 2 \\
\hline 8. & $35-40$ & 3 & $\mathrm{~F}$ & Average & Rural & No & University & Female & High & 1 \\
\hline 9. & -30 & 3,6 & $\mathrm{~F}, \mathrm{M}$ & Low & Rural & No & $\begin{array}{c}\text { Primary } \\
\text { school }\end{array}$ & Female & High & 2 \\
\hline 10. & $35-40$ & 4 & $\mathrm{~F}, \mathrm{~F}$ & High & Urban & No & University & Female & Average & 2 (Twins) \\
\hline 11. & $30-34$ & 4 & $\mathrm{M}$ & Low & Urban & No & University & Male & High & 2 \\
\hline 12. & $35-40$ & 6 & M & High & Urban & No & University & Female & Average & 2 \\
\hline 13. & $35-40$ & 3 & F & Average & Rural & Yes & $\begin{array}{c}\text { Secondary } \\
\text { school }\end{array}$ & Female & Average & 2 \\
\hline 14. & -30 & 3 & M & Average & Rural & No & $\begin{array}{c}\text { Secondary } \\
\text { school }\end{array}$ & Female & High & 2 \\
\hline 15. & $30-34$ & 4,6 & $\mathrm{~F}, \mathrm{~F}$ & Average & Rural & Yes, 6,F & $\begin{array}{c}\text { Secondary } \\
\text { school }\end{array}$ & Female & Low & 3 \\
\hline
\end{tabular}


A second pillar of the methodology consisted of an observation of the families in a grocery store setting. This method is a popular tool to study how children influence their parents' consumption (Thomas \& Garland 1993, O’Dougherty et al. 2006, Page et al. 2018). As none of the papers previously focused solely on the age group in the current study, it was added as a second data collection technique, it also further helps cancel out bias from the conducted interviews. Out of the 15 interview respondents, 4 claimed they never take their children with them grocery shopping. They were excluded for the second section of the study. From the remaining 11, participants, who claimed they did not take their children with them at least once in the past 10 shopping visits were also excluded, leaving a sample of 8 participants. The observation took place in the store, where the participants would normally go. Field observations were recorded of what item was being requested, selected or rejected, together with verbal and non-verbal communications between parent and child. Observations were coded into two main categories: where negotiation took place, and ones in which the child did not participate in the decision making. The requests of accompanying siblings (in one case) were not included.

\section{RESULTS}

\section{Brand preference}

The interviewed participants mentioned a vast amount of brands during the interviews that were in some form connected to their children. However, from the mentioned brands, the children only actually preferred less than half. Nearly half (44\%) of the brands mentioned as preferred brands or favourites for this age group were sweets and chocolate, one third (33\%) were dairy products, the remaining products were drinks targeted to children, a tuna and a meat manufacturing brand were also mentioned. While one father described a great preference for McDonalds, which he then admitted was one of his favourites too.

"But a preferred brand that is the ,non-plus ultra" is McDonalds. They recognize it anywhere, even when they only see the red colour, they note that's the same red as McDonalds." (Male, 30, Budapest).

Apart from preferred brands, brands were mentioned that are disliked by children.

"A pudding that they don't like is Paula, my daughter told me not to get that one" (Female, 34, Salgótraján).
When comparing the income levels of the respondents and their answers regarding their child's brand preferences, respondents who mentioned a greater number of brand preferences per child had a higher average income in comparison to the entire sample. A possible explanation could be, that families who have a higher income can afford more branded products. Furthermore, those respondents who named the most brands in connotation with their child also claimed that their child watches television on a daily basis. In addition, those who claimed to take their children with them shopping could recall more preferred brands of their children, while those who did not, or only seldom took their child with them, could not recall any brands. This finding suggests, that children to influence with their presence.

Results further showed that food allergies influence the brand usage of children. This phenomena leads to the fact, that children are indirectly influencing their parents' food purchase behaviour. During the interviews respondents reported, that if their child had some sort of food intolerance, this affected their consumption. Parent 6 , had two children with seed allergies. This meant that they could not eat nuts, various fruits and vegetables that have seeds, even certain type of fish, this meant restrictions on a vast amount of products too, that could contain traces of nuts. Two mothers had children with fructose allergies and various skin sensitivities. This meant that they could not eat anything containing sugar, the family prepared everything for themselves. Furthermore, all three respondents belonged to those who could hardly recall named brand preferences of their children. Discussing these allergies, participants talked about brands they could not purchase and ones that they are now loyal to, due to their child's allergy.

\section{Pre-school children's influence on family purchases}

One of the main influencing factors was whether the child is included in the food shopping routine of the family. Numerous different themes arose whilst discussing the question whether the children's presence influences the parents' shopping behaviour in any way. Those respondents who always took their children shopping emphasized how their shopping efficiency was influenced by the presence of the children. Interestingly, the same group also kept highlighting the purchase intentions they had for their child, even in their absence, as was the case with the 35 year old single mom: 
"Surely, I would buy the same stupid things for her if she was not there." (Female, 35, Salkszentmárton).

Another theme, namely the "asking" theme arose from respondents who seldom took their children with them to the store, the 37 year old mother of twins pointed out that:

"Yes, we have to buy something for them, if they want to buy sour cream, even if I don't need sour cream, then I have to buy some. But I usually limit it to one thing. If they see something else, I'll make them choose (Female, 37, Budapest).

The final theme arose of participants who claimed their children would not influence them whilst shopping. This was the case with three mothers, who either did not, or very rarely took their children shopping.

When asked if there are any products, where the child is allowed to make the purchase decision, all participants named several products, however, these differed. The majority named certain product categories as candy, dairy or bakery items. Other products named were pasta, meat products, drinks and fruit. From the contents of the interviews four main themes could be derived: shopping efficiency, purchase intentions, child's request as well as no influence. Participants, who always took their children shopping, mentioned shopping efficiency, highlighting the ways children can effect the shopping experience in either a positive or a negative way, while most comments were mainly negative.

\section{Observations}

In the coding's first negotiation category, the children were observed initiating requests and receiving either a positive or negative response. The children either asked or negotiated about the product they wanted. Two extreme cases were a child who was observed taking a product and putting it in the cart without asking, while another started a tantrum when their request was declined, this was the only conflict observed. Participants were also observed asking the child if they wanted an item. Out of the food categories observed within the negotiations, the following were purchased for the children: sweets and snacks $(31.3 \%)$ tied with dairy products $(31.3 \%)$, fruits and vegetables $(18.8 \%)$, drinks $(12.5 \%)$ and baked products $(6.3 \%)$. Out of the 20 observations, $60 \%$ of the selections were initiated by the child. Out of the 12 observations, $66 \%$ of the time, the adult agreed to a child's request. The items bought included Kinder Joy, Dörmi, Pöttyös tejsüti, Kubu drink, chips and cheese. Neither of the children specifically requested fruit or vegetable, but were included in the decision process. When participants initiated the purchase with the child, it was mostly to verify if an item should be bought or to ask the child to select a certain flavour. Different refusal strategies were applied: ranging from a short „no", to offering an explanation, to ignoring the child's request. Overall, in $75 \%$ of all observations, a child indicated a preference for a brand (for example, "Let's buy Dörmi"), or seemed to react positively to a child-directed marketing technique (one child asked for a certain cheese brand and added "I want the one with the Angry birds tattoo and not the Barbie one" that came with the product). Comparing the observations to the interview, it was interesting, that only three participants claimed the child has an influence on their shopping habits. From the remaining five, four participants gave into their children's request, one mom who claimed not to be influenced by her daughter bought two items that the child requested and two other items after asking her daughters opinion. 


\section{DISCUSSION}

The findings indicate that children can develop preferences for certain type of food brands even at such a young age. However, within this sample, their brand preferences were only detectible within food and beverage products. Furthermore, within the sample, children managed to influence their parents' purchase behaviours in numerous ways. Factors such as the child's involvement in the shopping process, family income, parents' relationship status, media consumption and medical conditions played a role in what brand preferences evolved in the children and how they then influenced their parents.

The paper also highlights the shifts in brand usage within families, in other words those products that families are likely to substitute when children arrive in their lives, underlining the findings of Koschate-Fischer et al. (2018). Half of the respondents claimed they replaced certain products due to their children. However, the only parent who claimed to have completely replaced the items purchased due to their child was the only single mother in the study:

"I did not eat salami, since my daughter loves it we have it at home. My kitchens content has been completely replaced since she was born. I won't buy two kinds of everything I prefer buying everything for her." (Female, 35, Szalkszentmárton).

Likewise, most respondents recalled switching food and beverage brands due to their children's preferences. The paper underlines the findings of Page et al. (2018), that children's influence on their parents is restricted to a couple of food categories, while the observations underlined that children often got a say in what brands were selected. The observational findings were partially in line with O'Dougherty et al. (2006), as type of food categories bought due to children's requests were very similar to the previous study. However, the Hungarian sample selected more branded products. Observations further underlined, that parents in the sample underestimated, the extent to how much their child influences their behaviour. At the same time, it has to be noted that parents who claimed never to take their children shopping were excluded from this part of the analysis. Finally, previous studies showed that brand awareness of preschool aged children exist (Kasler 2017), but the current sample suggests that they have actual preferred brands too.

\section{CONCLUSIONS}

The interviews propose, that brand preferences are likely to exist in children of this age group and that these, as well as other factors relating to the children influence their family purchases. The findings of this sample suggest that the children's influence on family decision making is limited to food products of direct use to children. Findings from the observations revealed that the children in the sample influenced their parents. However, the parents perceived children to have a smaller amount of influence on their purchase decision making, than they did. Findings indicated that parents underestimate the role their children have in purchasing decisions.

In order to give complete managerial implications, it is important to investigate the current topic in the perspective of retailers. Underlining that marketing to children is highly unethical if products are marketed in deceptive ways that only make the current child obesity epidemic of our time worse. However, retailers as well as manufacturers of various healthy product options can develop numerous strategies, to help build relationships with young consumers and their families, to help them gain a competitive advantage in an ethical manner.

The current research may also be supportive when considering the future of children's food marketing and even tackling the issue of childhood obesity, as the majority of preferred brands by children were sweets and snacks. It is the responsibility of the public health policy makers to take specific measures so that the content of food advertisements during children's advertisements promotes healthy food choices. As children are more involved with in the shopping process and exert a great amount of influence than their families often assume, it would be important to ease the amount of advertising noise a child has to deal with. Children are confronted with an overwhelming amount of stimuli during every grocery store visit. The observations showed, that children react positively to child-directed marketing techniques. Thus, it is important to make packaging and display materials of healthy products stand out more by using colours that are more appealing and memorable for this age group. Dairy, products were often selected by children, thus special focus needs to be placed on regulating the marketing for this specific product category. Finally, the paper underlines the importance of two underserved potential markets for food producers. One focusing on allergies and intolerances, the other being the single parent market. Families 
where children are prone to allergies turned out to be very brand loyal, as they knew exactly which brands were the ones their children could consume without any risks. Creating healthy brands targeting children with specific allergies could not only be extremely successful but also potentially make the lives of many families a lot easier. Single households where food demands of their child's is often placed before their own could also be a great potential market.

Unfortunately, the main limitation of the paper lies within the sample. Although in terms of regional heritage, the sample covers all regions of Hungary, the interviews were mainly conducted within the main cities. Up to this point, brand usage and preference for this age group, have not been studied in smaller suburbs and villages, thus a greater proportion of results could have brought interesting insights in this specific field. Another important internal validity threat lies within the interview itself. The interview was semi-structured, the guide was used at all times, however the interviewer had to phrase certain questions differently or even leave out irrelevant questions, which might have affected the answers of the participants slightly. Bias also needs to be discussed, as it influences the validity and reliability of study findings, while misinterpretation of data can have important consequences for practice (Smith \& Noble 2014). The possible power asymmetry between the interviewer and the interviewee can also lead to bias, as the interview is not an open everyday conversation between equal partners. It is the role of the researcher to make the participant feel comfortable to open up about the questions discussed so that counter-control does not take place by the participants withholding information. The current study still leaves numerous possibilities for further research in this specific field. The study is restricted to Hungary, it would be worth investigating the differences between other countries, such as a comparison between the CEE region and Western Europe. The link between different parenting styles and brand usage could also be an interesting field to further research.

\section{REFERENCES}

Berey, L. A., and Pollay, R. W. (1968), "The influencing role of the child in family decision making", Journal of Marketing Research, 5(1), 70-72. DOI: 10.1177/002224376800500109

Borgers, N., De Leeuw, E. and Hox, J. J. (2001), "Children as respondents in survey research: Cognitive development and response quality", Bulletin de Me'thodologie Sociologique, 66(1), 60-75. DOI: 10.1177/075910630006600106

Boyland, E. J., and Halford, J. C. (2013), "Television advertising and branding. Effects on eating behaviour and food preferences in children", Appetite, 62, 236-241. DOI: 10.1016/j. appet.2012.01.032

Carruth, B. R., Skinner, J. D., Moran III, J. D. and Coletta, F. (2000), "Preschoolers' food product choices at a simulated point of purchase and mothers' consumer practices", Journal of Nutrition Education, 32(3), 146-151. DOI: 10.1016/ S0022-3182(00)70542-5

Drenten, J., Peters, C. O., and Thomas, J. B. (2008), "An exploratory investigation of the dramatic play of preschool children within a grocery store shopping context", International Journal of Retail \& Distribution Management, 36(10), 831-855. DOI:10.1108/09590550810901017

Ekström, K. M. (2007), "Parental consumer learning or 'keeping up with the children", Journal of Consumer Behaviour: An International Research Review, 6(4), 203-217. DOI: 10.1002/ cb. 215

Fiates, G. M. R., De Mello Castanho Amboni, R. D. and Teixeira, E. (2008), "Consumer behaviour of Brazilian primary school students: findings from focus group interviews", International journal of consumer studies, 32(2), 157-162. DOI: 10.1111/j.1470-6431.2007.00661.x

Halford J. C. G., Boyland E. J., Hughes G. M., Oliveira L. P. and Dovey, T. M. (2007), "Beyondbrand effect of television food advertisements/ commercials on caloric intake and food choice of 5-7-year-old children", Appetite, 49(1), 263267. DOI: $10.1016 /$ j.appet.2006.12.003

Hite, C. F. and Hite, R. E. (1995), "Reliance on brand by young children", Journal of the Market Research Society, 37(2), 185-194. DOI: 10.1177/147078539503700204

Hsieh, Y. C., Chiu, H. C. and Lin, C. C. (2006), "Family communication and parental influence on children's brand attitudes", Journal of Business Research, 59(10-11), 1079-1086. DOI: /10.1016/j.jbusres.2006.09.016 
John, D. R. (1999), “Consumer socialization of children: A retrospective look at twenty-five years of research", Journal of consumer research, 26(3), 183-213. DOI: 10.1086/209559

Kasler, T. (2017), „Az óvodáskorú gyermekek televízió nézésének hatása a márkatudatosságukra és a fogyasztói magatartásukra", Marketing \& Management, 51(4), 39-48.

Kim, K. K., Williams, J. D. and Wilcox, G. B. (2016), "Kid tested, mother approved': the relationship between advertising expenditures and 'most-loved'brands", International Journal of Advertising, 35(1), 42-60. DOI: 10.1080/02650487.2015.1079947

Koschate-Fischer, N., Hoyer, W. D., Stokburger-Sauer, N. E. and Engling, J. (2018), "Do life events always lead to change in purchase? The mediating role of change in consumer innovativeness, the variety seeking tendency, and price consciousness", Journal of the Academy of Marketing Science, 46(3), 516-536. DOI: 10.1007/s11747-017-0548-3

Leibowitz, J., Rosch, J. T., Ramirez, E., Brill, J. and Ohlhausen, M. (2012), "A review of food marketing to children and adolescents: follow-up report", Federal Trade Comission.

Malota, E., Gyulavári, T., and Bogáromi, E. (2018), „\#Mutimiteszel: Élelmiszer vásárlási és fogyasztási preferenciák, étkezési szokások a magyar lakosság körében" EMOK 2018 Nemzetközi Tudományos Konferencia konferenciakötete. 710-720.

Maubach, N., Hoek, J., and McCreanor, T. (2009), “An exploration of parents' food purchasing behaviours". Appetite, 53(3), 297-302. DOI: 10.1016/j.appet.2009.07.005

McNeal, J. U. (1992), "The littlest shoppers", American Demographics, 14(2), 48-52.

O’Dougherty, M., Story, M. and Stang, J. (2006), "Observations of parent-child co-shoppers in supermarkets: children's involvement in food selections, parental yielding, and refusal strategies", Journal of nutrition education and behavior, 38(3), 183-188. DOI: 10.1016/j. jneb.2005.11.034

Owens, T. J., and Hofferth, S. L. (2001), "Children at the Millennium: Where Have We Come From? Where Are We Going?" (Vol. 6). Elsevier.

Page, B., Sharp, A., Lockshin, L. and Sorensen, H. (2018), "Parents and children in supermarkets: Incidence and influence", Journal of Retailing and Consumer Services, 40, 31-39. DOI: 10.1016/j.jretconser.2017.08.023

Pólya, É., and Horváth, Á. (2011), „Családtagok szerepének vizsgálata a családi vásárlási folyamatban néhány élelmiszer esetében". Élelmiszer, Táplálkozás és Marketing, 8(1-2), 19-24.

Pólya, É. (2012), „A gyermekek fogyasztói szocializációja és családi döntéshozatalban betöltött szerepe". Marketing \& Menedzsment, 46(3), 22-31.

Smith, J., and Noble, H. (2014), "Bias in research", Evidence-Based Nursing, 17(4), 100-101. DOI: 10.1136/eb-2014-101946

Spéder, Zs. (2003), „Az európai családformák változatossága. Párkapcsolatok, szülõi és gyerme ki szerepek az európai országokban az ezredfordulón". Századvég, 3, 1-47.

Thomas, A. and Garland R. (1993), "Supermarket shopping lists: their effect on consumer expenditure", International Journal of Retail Distribution Management, 21(2), 8-14. DOI: 10.1108/09590559310028040

Ward, S., and Wackman, D. B. (1972), “Children's purchase influence attempts and parental yielding", Journal of Marketing Research, 9(3), 316319. DOI: $10.1177 / 002224377200900312$
Tímea Tina Kásler, PhD student timea.toth6@uni-corvinus.hu Corvinus University of Budapest 